\title{
Human Papillomavirus Infections in Primary Care
}

\author{
Folashade Ogunmodede, MD; Steven H. Yale, MD; Bruce Krawisz, MD; \\ Gregory C. Tyler, MD and Anthony C. Evans, MD, PhD
}

\begin{abstract}
Cervical cancer continues to be a leading cause of mortality worldwide. The incidence and mortality associated with invasive cervical cancer have declined significantly in developed countries due to widespread availability of screening with the Papanicolaou (Pap) test. However, the incidence and prevalence of non-invasive cervical intraepithelial neoplasms and genital warts related to oncogenic and nononcogenic strains of human papilloma viruses (HPV) have remained relatively stable. Recent advances in molecular diagnostics have resulted in improved characterization of various HPV types and have led to changes in terminology of Pap test findings. Changes in nomenclature may lead to confusion among primary care providers regarding how best to further evaluate abnormal cytological results. This article provides a concise overview of the approach to the treatment of genital warts and management of abnormal cervical cytology based on guidelines from the American Society of Colposcopy and Cervical Pathology. It also reviews advances in HPV vaccine development and the new recombinant vaccine recently approved for use in the United States.
\end{abstract}

Keywords: Genital warts; HPV; Pap test

$\mathrm{C}$ $5,000,000$ cases occurring annually and a $50 \%$ case fatality rate. ${ }^{1}$ Currently, cervical cancer is the sixth most common cancer among women in the United States and ranks 13th among cancer-related deaths. ${ }^{2}$ It is estimated that in the United States in the year 2007, 11,150 new cases of cervical cancer will be identified and 3,670 deaths will be attributed to this disease. ${ }^{2,3}$ Over the last 50 years, the incidence and mortality of invasive cervical cancer in the United States and in other developed countries has declined by nearly $70 \%$ due to the widespread use of cytological screening with the Papanicolaou (Pap) test resulting in the early detection and treatment of abnormal cervical cytology and intraepithelial neoplasia. ${ }^{4}$ Over the past several years, screening recommendations have become available from various organizations, and screening guidelines in most primary care practices in this country are based on these recommendations. ${ }^{5-7}$

\section{Epidemiology of HPV Infection}

Cervical cancer is strongly associated with human papillomavirus (HPV) infection, a common sexually-

Reprint Requests: Folashade Ogunmodede, MD, Department of Internal Medicine, Marshfield Clinic, 1000 North Oak Avenue, Marshfield, WI 54449, Tel: 7I5-387-5537, Fax: 7I5-389-3808, Email: ogunmodede.folashade@marshfieldclinic.org transmitted disease, and develops as a result of persistent infection with so-called high-risk or oncogenic types of HPV. 8 ,9 Data from the 2003-2004 National Health and Nutrition Examination Survey found a $26.8 \%$ overall prevalence of HPV infection in self-collected vaginal samples from women 14 to 59 years old in the United States. ${ }^{10}$ Epidemiological studies have shown that acquisition of HPV infection occurs within 1 to 2 years of onset of sexual activity in adolescent females and, in this group, the prevalence of HPV by polymerase chain reaction (PCR) can be as high as 64\%. ${ }^{11}$ In general, the prevalence of HPV infection is inversely related to age and increases with the number of sexual partners. Peak incidence of infection occurs in women aged 15 to 25 years. ${ }^{12-15}$ There may be a smaller peak in women over the age of 65 years. ${ }^{16}$ One British study showed an increase in acquisition of the infection among HPV-negative women older than 51 years of age. ${ }^{17}$ The prevalence of HPV infections is thought to be lower in men than in women, but one study of 18 to 70 -yearold men attending a sexually-transmitted disease clinic found a $28.2 \%$ prevalence of HPV infection. ${ }^{18}$ Another study found that $20 \%$ of uncircumcised and $5.5 \%$ of circumcised sexually active men had penile HPV by PCR. ${ }^{19}$ 
HPV is also the causative organism in genital warts, which are prevalent in individuals who are immunosuppressed. Both genital warts and cervical cancer can be more severe and resistant to treatment in people infected with the human immunodeficiency virus (HIV). ${ }^{20}$ As a result of the HIV epidemic, there has been a concomitant increase in the incidence of anal squamous cell carcinoma and anal carcinoma in situ, two conditions thought to be associated with persistent HPV infection. ${ }^{21}$

\section{Viral Genotypes}

HPV is a DNA virus belonging to the papovavirus family. There are over 100 subtypes of HPV based on differences in DNA sequences. Approximately 40 subtypes are associated with genital tract infection. These are divided into low-risk types (e.g., HPV 6 and 11), which are most commonly found in patients with condyloma acuminatum (i.e., genital warts) and high-risk types (e.g., HPV 16 and 18) associated with approximately $70 \%$ of invasive cervical cancers and over $90 \%$ of high-grade intraepithelial lesions. ${ }^{4}$ Other high-risk types include HPV 31, 33, 35, 39, 45, 51, 52, 56, 58, 59 and 68. Infection with multiple HPV types can also occur, especially in individuals with visible genital warts.

HPV cannot be cultured in vitro. However, HPV infections with the more common high-risk types can be detected by DNA amplification methods such as PCR or the hybrid capture assay. 22,23 Most PCR techniques are not standardized or validated and may only detect a few of the high-risk HPV types. The Digene Hybrid Capture 2 (HC2) is the only Food and Drug Administration-approved DNA test. HC2 is a signal-amplified, nucleic acid test that provides standardized, objective results for detecting 13 HPV DNA types associated with cervical cancer (i.e., HPV 16, 18, 31, 33, 35, 39, 45, 51, $52,56,58,59$ and 68) and five low-risk types associated with genital warts (i.e., HPV 6, 11, 42, 43 and 44). The test has been validated and has a sensitivity of $>96 \%$ for detection of high-grade cervical intraepithelial neoplasm or cancer, when used in conjunction with cytology. ${ }^{24}$

\section{Genital Warts}

Approximately $30 \%$ of all genital HPV infections are clinically recognizable as anogenital warts. These painless, fleshy lesions have a predilection for moist, warm surfaces. The diagnosis is easily made based on direct visual inspection. 4,25,26 Genital warts are described as acuminate, papular or macular lesions. The presence of visible lesions in association with oncogenic types of HPV resulting in carcinoma in situ is sometimes referred to as Bowen's disease, while the presence of giant condylomata associated with nononcogenic types of HPV is referred to as a BuschkeLowenstein tumor. ${ }^{4}$

The most common sites for genital warts in female patients are the ectocervix, labia, vagina, perineum and perianal area. The presence of intra-anal warts should raise the suspicion of receptive anal intercourse, and such patients should undergo cytological testing of cells from the anorectal zone, a digital rectal exam and direct visualization via anoscopy or sigmoidoscopy if the anal Pap test reveals cytological abnormalities. $^{21}$

Genital wart lesions generally start as small papules, which may then enlarge and coalesce via direct autoinoculation. They may occasionally grow to become very large masses, which can become secondarily infected, bleed or cause pain from direct pressure. The diagnosis of genital warts can be confirmed, if necessary, by biopsy. Indications for biopsy include an unclear diagnosis, non-response to or worsening during therapy, an immunocompromised patient or an ulcerated, fixed or pigmented lesion. There is no indication for HPV molecular testing, such as PCR or hybrid capture assay, for the diagnosis of genital warts. ${ }^{25}$

There is no cure for HPV infection, and it should be emphasized to patients that they still are able to transmit the virus even in the absence of visible warts. There is no requirement for partner notification or treatment for genital warts. Additionally, genital warts and subclinical HPV infection may also occur in homosexual women who should be subjected to the same screening guidelines as their heterosexual counterparts. Thus, HPV infection may be acquired through non-penetrating intercourse. Barrier contraception, although important, does not provide complete protection, because oftentimes lesions are located on the vulva, labia and perineum. In spite of the lack of a specific cure, HPV colonization can be reversed (including pre-invasive neoplasia) by normal immune processes.

The goal of treatment of genital warts is eradication of visible and/or symptomatic warts. Treatment may be patient- or provider-administered, with the choice of treatment influenced by patient preference, provider experience, cost and convenience of treatment, anatomic location and extent of the warts. The presence of cervical and intra-anal warts is an indication for specialist referral.25,27 Prior to treatment, women with cervical warts who have not received a recent Pap test must have one in order to exclude any abnormal cytological findings that may require further evaluation, such as gynecological referral for colposcopy.

Treatment options are highlighted in table 1.25 If lesions have not improved after three provider-administered treatments or have not cleared completely after six treatments, consideration should be given to switching to a different treatment modality. For patients who failed initial therapy, a combination therapy with two different regimens may also be considered. However, this is not always successful and may be associated with an increased frequency of side effects.

Side effects of treatment are minimal and are typically related to pain and irritation at the application site of the lesion. Complications are rare and include scarring, hypo- or hyperpigmentation and chronic pain syndromes such as 
Table 1. Treatment options for genital warts ${ }^{25}$

Patient-administered

- $0.5 \%$ podofilox solution applied to visible warts twice daily for 3 days followed by 4 days of no treatment, repeated up to four cycles

- $5 \%$ imiquimod (Aldara) cream applied at bedtime for 6 to 10 hours 3 times a week for up to 16 weeks

Provider-administered

- Cryotherapy with liquid nitrogen applied every 1 to 2 weeks

- $10 \%$ to $25 \%$ podophyllin in a compound tincture of benzoic applied weekly

- $80 \%$ to $90 \%$ Trichloroacetic or Bichloroacetic acid applied to lesions and repeated weekly

- Surgical removal by curettage, shave excision, laser or electro surgery

- Intralesional interferon injection

vulvodynia. The risk of recurrence after treatment is high, particularly within the first 3 months.

In pregnant women, treatment options are limited to cryotherapy, trichloroacetic acid treatment, and surgical removal. Podophyllin-derived therapies and imiquimod are specifically contraindicated in pregnancy. ${ }^{25}$ Genital warts are not an indication for cesarean section, unless there is obstruction of the birth canal.

\section{Screening for Cervical Cancer}

The goal of screening with a Pap test is to identify and treat any high grade squamous intraepithelial lesions (HSIL), which are associated with an increased risk of invasive cervical cancer. Most practice guidelines recommend commencement of screening at 21 years of age or within 3 years of onset of sexual activity, whichever comes first. ${ }^{5-7}$ In women with HIV/AIDS, the Pap test should be obtained twice during the first year after diagnosis of HIV infection and, if the results are normal, annually thereafter. ${ }^{23,27}$ Some experts also recommend anal Pap tests annually for HIV-positive and every 2 to 3 years for HIV-negative bisexual and homosexual men. ${ }^{21}$

Screening should occur annually with the conventional Pap test or every 2 years with the liquid-based test (ThinPrep System, Cytyc, Marlborough, MA) until the age of 30 , following which screening can be every 2 to 3 years if the woman is not immunosuppressed and has had 3 consecutive normal Pap tests. Women aged 65 to 70 years or older who have had 3 consecutive normal Pap tests in the preceding 10 years need not continue screening. ${ }^{5}$ Women who have undergone total hysterectomy for a documented benign reason do not require further screening with a Pap test. This does not include women who have had a subtotal hysterectomy with the cervix still present, as they are still subject to the screening guidelines.

Cytology, however, is not the recommended method of screening women suspected of having endometrial or endocervical abnormalities and is only $50 \%$ to $75 \%$ effective in identifying glandular neoplasm. These guidelines also do not apply to immunosuppressed or immunocompromised women or to those exposed to diethylstilbestrol in utero who should continue receiving annual Pap tests irrespective of age, method of obtaining the Pap or presence of hysterectomy. In addition, these guidelines do not apply to women who have been treated for cervical cancer and who require ongoing surveillance.

The guidelines also recommend using the liquid-based Pap test because of its decreased likelihood of unsatisfactory samples, while still maintaining equivalent sensitivity as compared to the conventional Pap test. ${ }^{28,29}$ Liquid-based Pap tests provide the added value and convenience of reflex testing for HPV following an abnormal cytological result. 30,31 For endocervical neoplasia and atypical glandular cells (AGC), liquid-based testing is superior to a conventional "smear" technique as it increases the specificity. 32

\section{Classification of Cervical Cytology}

The criteria for describing cytological abnormalities identified on the Pap test are based on the Bethesda System of classification and were modified in 2001.33 This change incorporated the relatively new technologies of the liquidbased Pap test and genetic testing for HPV DNA. This cytological terminology may introduce confusion regarding the appropriate triage and management decisions in patients with abnormal test results.

The 2001 Bethesda system of classification of Pap tests is a revised method of uniform laboratory reporting of cervical cytology results. It consists of five parts of which at least three are usually required. The first component of the report is a comment regarding the specimen's adequacy for interpretation which is stated as either satisfactory or unsatisfactory. If it is the latter, then further clarification as to whether the specimen was rejected or analyzed is provided. The second component is not required and is a general categorization of the specimen as either positive or negative for epithelial abnormality. The third and most important part of the Bethesda system is the interpretation of the result, which consists of an expanded description based on the type of epithelial cell abnormality (e.g., squamous vs. glandular), extent of atypical cell transformation and the presence of organisms or endometrial cells. If the laboratory utilizing the system has an automated review system or performs additional testing, such as DNA testing, this information must also be reported and is the fourth component of the Bethesda system. Last is the comments section which is also optional. 
Comments usually take the form of a suggestion and may reference practice guidelines for further management of the patient as clinically warranted.

\section{Management of Abnormal Cervical Cytological Results}

Glandular cell abnormalities described in the revised Bethesda system include the following categories: (1) AGC, (2) AGC, favor cell growth (neoplastic changes), (3) endocervical adenocarcinoma in situ (AIS), and (4) adenocarcinoma. The revised Bethesda classification system reports abnormal intraepithelial cervical cytological results into four categories which include: (1) atypical squamous cells of undetermined significance (ASC-US), (2) ASC-cannot exclude high-grade squamous intraepithelial lesions (ASC-H), (3) low-grade squamous intraepithelial lesions (LSIL) and (4) HSIL. ${ }^{34-38}$

ASC-US

Management of ASC-US may include repeating cytologic screening through Pap tests, HPV DNA testing if a specimen is available, or immediate colposcopy. When a liquid-based Pap test is utilized, reflex testing for high-risk HPV subtypes by PCR or HC2 is the preferred method of managing ASCUS. If a woman tests positive for high-risk HPV DNA, she should then be referred for colposcopy. If the DNA test is negative, a Pap test should be repeated within 12 months.

If the decision is made to repeat cytologic screening, it should be performed at 4 to 6 month intervals until two consecutive negative results are obtained. Subsequently, the woman may go back to routine screening. Any repeat result showing atypical squamous cells warrants immediate specialty referral for colposcopy. These recommendations also apply to pregnant women. However, all immunosuppressed women with ASC-US, including those who are HIV positive, must be referred immediately for colposcopy.

Typically, women who are sent for immediate colposcopy are biopsied. Preinvasive cervical abnormalities identified from histological specimens obtained at colposcopy are reported as cervical intraepithelial neoplasia (CIN) with grades ranging from mild (CIN-1) to severe (i.e., cervical cancer in situ) (CIN-3). If a biopsy is negative for a CIN lesion, then routine screening with a Pap test is recommended. A biopsyconfirmed CIN lesion is treated according to guidelines published elsewhere and is beyond the scope of this review. ${ }^{37}$

\section{$A S C-H$}

Women with atypical squamous cells and a possible HSIL require immediate colposcopy and biopsy. If $\mathrm{CIN}$ is confirmed by biopsy, then treatment is recommended according to the American Society for Colposcopy and Cervical Pathology (ASCCP) guidelines. ${ }^{37}$ If no CIN lesion is identified, then the cytologic, histopathologic, and colposcopic results should be reevaluated. If, upon review, the results remain negative, then cytologic screening should be repeated at 6 and 12 months. Alternatively, HPV DNA testing should be performed at 12 months. The presence of atypical squamous cells on repeat cytologic testing or a positive HPV DNA test result is an indication for repeating colposcopy.

\section{LSIL}

Approximately $15 \%$ to $30 \%$ of women with LSIL on cytology will have high-grade CIN on histology. ${ }^{38}$ The remainder will either have no lesion or have CIN-1 on biopsy. In the past, a conservative approach of monitoring women with LSIL by repeat cytology was advocated because of the tendency for these lesions to spontaneously regress. However, due to concerns related to the high incidence of patients lost to follow-up, the ASCCP now recommends that all women with LSIL be referred for colposcopy (table 2). This allows for early detection of women with significant disease and alleviates the concern that patients will be lost to follow-up. Adolescents and postmenopausal women deemed as reliable for follow-up should still be managed per ASC-US guidelines.

If no CIN is detected on biopsy, repeat cytology at 6-month and 12-month intervals or DNA testing for high risk HPV types at 12 months is recommended. If either of these tests is negative, routine screening is recommended. If cytology detects atypical squamous cells, ASC-H or HSIL or if HPV DNA is positive, patients should be referred for colposcopy. If the biopsy is positive for CIN, management should follow the ASCCP guidelines. ${ }^{37}$

\section{$H S I L$}

HSIL is reported to account for $<1 \%$ of all cytologic abnormalities identified. Approximately $75 \%$ of women with HSIL will have CIN grade $2 / 3$ on biopsy, and up to $2 \%$ will have invasive cancer. 37,38 The ASCCP recommends immediate colposcopy with endocervical assessment. For non-pregnant females, immediate excision is another option. ${ }^{37}$

\section{When to Refer to a Specialist}

All patients with squamous cell carcinoma in situ or any glandular cell atypia, as well as those over 40 years of age with the presence of endometrial cells on cytologic screening should be referred to a specialist for colposcopy, endocervical sampling and/or endometrial sampling, as appropriate.36,37 Any patient with atypical squamous cells on repeat cytologic testing and women with high-grade lesions should also be referred for colposcopy. Decisions regarding referral for LSIL can be appropriately individualized depending upon the reliability of follow-up for each individual patient. With respect to genital warts, the presence of endocervical or rectal warts is an indication for specialist referral. ${ }^{25}$

\section{HPV Vaccine}

Studies have shown that non-infective viral capsids composed of HPV are immunogenic. Phase I and II studies have demonstrated the efficacy of vaccination with L1 viral-like 
Table 2. Management of abnormal cervical cytology 34,35

\begin{tabular}{|c|c|c|c|}
\hline Cytological diagnosis & $\begin{array}{l}\text { HPV DNA test } \\
\text { required }\end{array}$ & Management & $\begin{array}{l}\text { Histological } \\
\text { diagnosis }\end{array}$ \\
\hline Negative for intraepithelial lesion & No & No further intervention. Repeat Pap in 1 year & None \\
\hline \multirow{4}{*}{$\begin{array}{l}\text { ASC-US* } \\
\text { (Reflex HPV DNA test, then } \\
\text { referral if positive is preferred) }\end{array}$} & Yes & $\begin{array}{l}\text { If HPV+, immediate colposcopy } \\
\text { If HPV-, repeat Pap in } 12 \text { months }\end{array}$ & $\begin{array}{l}\text { CIN } 1 \text { most likely } \\
\text { None }\end{array}$ \\
\hline & No & $\begin{array}{c}\text { Repeat Pap in } 4 \text { to } 6 \text { months, if negative twice, } \\
\text { resume annual Pap }\end{array}$ & None \\
\hline & No & If $\geq$ ASC on repeat Pap, refer for colposcopy & CIN 1, 2, 3 \\
\hline & No & $\begin{array}{l}\text { Alternatively, refer immediately for colposcopy. } \\
\text { Also refer if immunosuppressed } \dagger\end{array}$ & CIN 1, 2, 3 \\
\hline \multirow[t]{3}{*}{ ASC-H } & No & Immediate colposcopy is preferred & CIN 1, 2, 3 \\
\hline & No & $\begin{array}{l}\text { If negative histology, re-evaluate all tests, (if still } \\
\text { negative for CIN, but ASC-H) repeat Pap at } 6 \text { \& } \\
12 \text { months. If negative, resume annual Pap }\end{array}$ & None \\
\hline & $\begin{array}{l}\text { Yes if histology } \\
\text { is negative }\end{array}$ & $\begin{array}{l}\text { Or test HPV DNA in } 12 \text { months and repeat } \\
\text { colposcopy if positive }\end{array}$ & CIN 1, 2, 3 \\
\hline \multirow[t]{3}{*}{ LSIL $\neq$} & No & Immediate colposcopy preferred & CIN 1 most likely \\
\hline & No & $\begin{array}{c}\text { Repeat Pap at } 6 \& 12 \text { months, if } \leq \text { ASC-US, } \\
\text { then resume annual Pap }\end{array}$ & None \\
\hline & Yes & $\begin{array}{l}\text { Test HPV at } 12 \text { months, if positive refer } \\
\text { for colposcopy }\end{array}$ & CIN 1, 2, 3 \\
\hline \multirow[t]{2}{*}{$\mathrm{HSIL}_{\S}$} & No & Immediate colposcopy & $\begin{array}{l}\text { CIN 2, } 3 \text { or } \\
\text { carcinoma in situ }\end{array}$ \\
\hline & No & $\begin{array}{l}\text { Immediate excision if not pregnant, i.e. assume } \\
\text { and treat as high-grade CIN or invasive cancer }\end{array}$ & None \\
\hline
\end{tabular}

*In postmenopausal women, either refer for immediate colposcopy or if there is evidence of atrophy, treat with vaginal estrogen, then repeat cytology,

if ASC-US persists, then refer for colposcopy.

†Includes HIV positive women.

\# If patient is reliable, okay to repeat Pap in 6 months, since $>70 \%$ of LSIL are CIN-1 on histology.

$\S$ Rarest outcome of Pap test, $<1 \%$.

ASC, atypical squamous cells; ASC-H, atypical squamous cells-cannot exclude high-grade squamous intraepithelial lesions; ASC-US, atypical squamous cells of undetermined significance; CIN, cervical intraepithelial neoplasia; HIV, human immunodeficiency virus; HPV, human papillomavirus; HSIL, high-grade squamous intraepithelial lesions; LSIL, low-grade squamous intraepithelial lesions.

particles for specific HPV genotypes at protecting against the development of infection. ${ }^{39,40}$ There are two vaccines which have recently been developed, Gardasil (Merck, Whitehouse Station, NJ) and Cervarix (GlaxoSmithKline, Research Triangle Park, NC).

Gardasil is a quadrivalent recombinant vaccine containing L1 viral-like particles for HPV types 6, 11, 16 and $18 .{ }^{41}$ In a phase III prospective, randomized, double-blind, placebocontrolled study (FUTURE II), over 12,000 women aged 16 to 26 years from 13 countries were randomized to receive either Gardasil or a placebo vaccine. ${ }^{42}$ The vaccine was administered in a three-dose regimen given at 0,2 and 6-month intervals. The primary outcome was the incidence of CIN-2/3 or AIS. The women were followed for up to 17 months after completion of the vaccine regimen. Gardasil prevented $100 \%$ of all cases of CIN-2/3 or AIS associated with HPV types 16 and 18 in the vaccine group compared to 21 cases of CIN-2/3 or AIS in the placebo group. Secondary analysis of women who developed HPV infection during the vaccination period or who violated the study protocol also demonstrated a $97 \%$ reduction in the incidence of CIN-2/3 or AIS in the vaccine group (1 case) compared to the placebo group (36 cases). There were no severe side effects associated with the vaccine. However, long-term efficacy studies are not yet available. 
Gardasil was evaluated and approved within a 6-month period by the Food and Drug Administration through a priority review process (which is only available for products having the potential to provide significant health benefits). ${ }^{43}$ The approval was announced on June 8, 2006, and 2 weeks later on June 23, 2006 the Advisory Committee on Immunization Practices (ACIP) of the Centers for Disease Control recommended immunization with Gardasil to protect against HPV infections. ${ }^{44}$

According to the new ACIP guidelines, Gardasil will now be routinely administered as part of the childhood immunization schedule to girls at age 11 or 12 years, with the allowance for the vaccination as early as 9 years of age, if necessary. ${ }^{44}$ The vaccine should be administered prior to the onset of sexual activity and subsequent exposure to the virus, as this is when it provides maximum benefit. However, the ACIP also recommends immediate vaccination of all girls and women 13 to 26 years of age, irrespective of current sexual practice or presence of HPV infection, because they can still derive some benefit from the vaccine. Gardasil is administered as a $0.5 \mathrm{cc}$ intramuscular injection at 0,2 and 6 month intervals, and preliminary results show efficacy up to 4.5 years. At present, Gardasil is contraindicated in pregnant and lactating women. The vaccine does not take the place of routine screening for cervical cancer or treatment of symptomatic genital warts. It is unclear what impact, if any, Gardasil will have on clearance of an established infection or intraepithelial neoplasia, and research is ongoing. For now the vaccine is only licensed for use prophylactically.

\section{Conclusion}

HPV infection is a common, treatable, and preventable infection in women. Early detection and appropriate management of pre-invasive lesions are crucial for preventing invasive squamous malignancies, particularly as mounting evidence suggests that such tumors in the rectum, penis, vagina and vulva may also be related to persistent HPV infection. ${ }^{45-54}$ The introduction of the liquid-based Pap test and molecular diagnostics techniques has provided new approaches to the management of cytological abnormalities. The HPV vaccine is expected to further decrease the acquisition of HPV infections, the precursor of invasive malignancies, as well as the morbidity associated with genital warts. However, until more information regarding the vaccine's long-term efficacy becomes available, the Pap test will continue to be an important tool in the prevention of invasive cervical cancer.

\section{Acknowledgments}

The authors thank Marshfield Clinic Research Foundation for its support through the assistance of Jennifer Hayes, Linda Weis, and Alice Stargardt in the preparation of this manuscript.

\section{References}

1. Bulletin of the World Health Organization (BLT). World Health Organization Web site. Available at:

http://www.who.int/bulletin/volumes/84/2/. Accessed May 22, 2006.

2. Cancer Facts and Figures 2002. American Cancer Society Web site. Available at:

http://www.cancer.org/downloads/STT/CancerFacts\&Figures2 002TM.pdf. Accessed January 24, 2007.

3. Ries LAG, Harkins D, Krapcho M, Mariotto A, Miller BA, Feuer EJ, Clegg L, Eisner MP, Horner MJ, Howlader N, Hayat M, Hankey BF, Edwards BK, eds. SEER Cancer Statistics Review, 1975-2003, National Cancer Institute. Bethesda, MD. Available at:

http://seer.cancer.gov/csr/1975_2003/index.html. Accessed June 20, 2007.

4. Scott JR, Gibbs RS, Karlan BY, Haney AF, eds. Danforth's obstetrics and gynecology, Ninth edition. Philadelphia, PA: Lippincott Williams and Wilkins; 2003.

5. Screening for Cervical Cancer, January 2003. U.S. Preventive Services Task Force Web site. Available at: http://www.ahrq.gov/clinic/uspstf/uspscerv.htm. Accessed January 24, 2007.

6. Smith RA, Cokkinides V, von Eschenbach AC, Levin B, Cohen C, Runowicz CD, Sener S, Saslow D, Eyre HJ; American Cancer Society. American Cancer Society guidelines for the early detection of cancer. CA Cancer J Clin 2002;52:8-22.

7. Saslow D, Runowicz CD, Solomon D, Moscicki AB, Smith RA, Eyre HJ, Cohen C; American Cancer Society. American Cancer Society guideline for the early detection of cervical neoplasia and cancer. CA Cancer J Clin 2002;52:342-362.

8. Clifford GM, Smith JS, Aguado T, Franceschi S. Comparison of HPV type distribution in high-grade cervical lesions and cervical cancer: a meta-analysis. Br J Cancer 2003;89: 101-105.

9. Einstein MH, Goldberg GL. Human papillomavirus and cervical neoplasia. Cancer Invest 2002;20:1080-1085.

10. Dunne EF, Unger ER, Sternberg M, McQuillan G, Swan DC, Patel SS, Markowitz LE. Prevalence of HPV infection among females in the United States. JAMA 2007;297:813-819.

11. Tarkowski TA, Koumans EH, Sawyer M, Pierce A, Black CM, Papp JR, Markowitz L, Unger ER. Epidemiology of human papillomavirus infection and abnormal cytologic test results in an urban adolescent population. J Infect Dis 2004; 189:46-50.

12. Peyton CL, Gravitt PE, Hunt WC, Hundley RS, Zhao M, Apple RJ, Wheeler CM. Determinants of genital human papillomavirus detection in a US population. J Infect Dis 2001;183:1554-1564.

13. Sellors JW, Karwalajtys TL, Kaczorowski J, Mahony JB, Lytwyn A, Chong S, Sparrow J, Lorincz A; Survey of HPV in Ontario Women Group. Incidence, clearance and predictors of human papillomavirus infection in women. CMAJ 2003;168:421-425.

14. Sellors JW, Mahony JB, Kaczorowski J, Lytwyn A, Bangura H, Chong S, Lorincz A, Dalby DM, Janjusevic V, Keller JL. Prevalence and predictors of human papillomavirus infection in women in Ontario, Canada. Survey of HPV in Ontario Women (SHOW) Group. CMAJ 2000;163:503-508.

15. Ho GY, Bierman R, Beardsley L, Chang CJ, Burk RD. Natural history of cervicovaginal papillomavirus infection in young women. N Engl J Med 1998;338:423-428. 
16. Herrero R, Schiffman MH, Bratti C, Hildesheim A, Balmaceda I, Sherman ME, Greenberg M, Cardenas F, Gomez V, Helgesen K, Morales J, Hutchinson M, Mango L, Alfaro M, Potischman NW, Wacholder S, Swanson C, Brinton LA. Design and methods of a population-based natural history study of cervical neoplasia in a rural province of Costa Rica: the Guanacaste Project. Rev Panam Salud Publica 1997; 1:362-375.

17. Grainge MJ, Seth R, Guo L, Neal KR, Coupland C, Vryenhoef P, Johnson J, Jenkins D. Cervical human papillomavirus screening among older women. Emerg Infect Dis 2005; 11:1680-1685.

18. Baldwin SB, Wallace DR, Papenfuss MR, Abrahamsen M, Vaught LC, Kornegay JR, Hallum JA, Redmond SA, Giuliano AR. Human papillomavirus infection in men attending a sexually transmitted disease clinic. J Infect Dis 2003; 187:1064-1070.

19. Castellsague X, Bosch FX, Munoz N, Meijer CJ, Shah KV, de Sanjose S, Eluf-Neto J, Ngelangel CA, Chichareon S, Smith JS, Herrero R, Moreno V, Franceschi S; International Agency for Research on Cancer Multicenter Cervical Cancer Study Group. Male circumcision, penile human papillomavirus infection, and cervical cancer in female partners. N Engl J Med 2002;346:1105-1112.

20. Silverberg MJ, Ahdieh L, Munoz A, Anastos K, Burk RD, CuUvin S, Duerr A, Greenblatt RM, Klein RS, Massad S, Minkoff H, Muderspach L, Palefsky J, Piessens E, Schuman P, Watts H, Shah KV. The impact of HIV infection and immunodeficiency on human papillomavirus type 6 or 11 infection and on genital warts. Sex Transm Dis 2002; 29:427-435.

21. Goldie SJ, Kuntz KM, Weinstein MC, Freedberg KA, Welton ML, Palefsky JM. The clinical effectiveness and costeffectiveness of screening for anal squamous intraepithelial lesions in homosexual and bisexual HIV-positive men. JAMA 1999;281:1822-1829.

22. Peyton CL, Schiffman M, Lorincz AT, Hunt WC, Mielzynska I, Bratti C, Eaton S, Hildesheim A, Morera LA, Rodriguez AC, Herrero R, Sherman ME, Wheeler CM. Comparison of PCRand hybrid capture-based human papillomavirus detection systems using multiple cervical specimen collection strategies. J Clin Microbiol 1998;36:3248-3254.

23. Sailors J, Gander R, Saboorian MH, Berkley P, Foster B, Ashfaq R. Stability of PreservCyt for Hybrid Capture (HC II) HPV test. Diagn Cytopathol 2005;32:260-263.

24. Solomon D, Schiffman M, Tarone R; ALTS Study group. Comparison of three management strategies for patients with atypical squamous cells of undetermined significance: baseline results from a randomized trial. J Natl Cancer Inst 2001;93:293-299.

25. Centers for Disease Control and Prevention, Workowski KA, Berman SM. Sexually transmitted diseases treatment guidelines, 2006. MMWR Recomm Rep 2006;55:1-94.

26. von Krogh G, Lacey CJ, Gross G, Barrasso R, Schneider A. European course on HPV associated pathology: guidelines for primary care physicians for the diagnosis and management of anogenital warts. Sex Transm Infect 2000;76:162-168.

27. Kaplan JE, Masur H, Holmes KK; USPHS; Infectious Disease Society of America. Guidelines for preventing opportunistic infections among HIV-infected persons-2002.

Recommendations of the U.S. Public Health Service and the Infectious Diseases Society of America. MMWR Recomm Rep 2002;51:1-52.

28. Castle PE, Solomon D, Hildesheim A, Herrero R, Concepcion Bratti M, Sherman ME, Cecilia Rodriguez A, Alfaro M, Hutchinson ML, Terence Dunn S, Kuypers J, Schiffman M. Stability of archived liquid-based cervical cytologic specimens. Cancer 2003;99:89-96.
29. Fremont-Smith M, Marino J, Griffin B, Spencer L, Bolick D. Comparison of the SurePath liquid-based Papanicolaou smear with the conventional Papanicolaou smear in a multisite direct-to-vial study. Cancer 2004;102:269-279.

30. Cox JT, Lorincz AT, Schiffman MH, Sherman ME, Cullen A, Kurman RJ. Human papillomavirus testing by hybrid capture appears to be useful in triaging women with a cytologic diagnosis of atypical squamous cells of undetermined significance Am J Obstet Gynecol 1995;172:946-954.

31. Morin C, Bairati I, Bouchard C, Fortier M, Roy M, Moore L, Meisels A. Managing atypical squamous cells of undetermined significance in Papanicolaou smears. J Reprod Med 2001;46:799-805.

32. Wang N, Emancipator SN, Rose P, Rodriguez M, Abdul-Karim FW. Histologic follow-up of atypical endocervical cells. Liquid-based, thin-layer preparation vs. conventional Pap smear. Acta Cytol 2002;46:453-457.

33. Solomon D, Davey D, Kurman R, Moriarty A, O'Connor D, Prey M, Raab S, Sherman M, Wilbur D, Wright T Jr, Young N; Forum Group Members; Bethesda 2001 Workshop. The 2001 Bethesda System: terminology for reporting results of cervical cytology. JAMA 2002;287:2114-2119.

34. Wright TC Jr, Cox JT, Massad LS, Twiggs LB, Wilkinson EJ; ASCCP-Sponsored Consensus Conference. 2001 Consensus Guidelines for the management of women with cervical cytological abnormalities. JAMA 2002;287:2120-2129.

35. Algorithms for the management of abnormal cervical cytology. American Society for Colposcopy and Cervical Pathology Web site. Available at: http://www.asccp.org/pdfs/consensus/algorithms.pdf. Accessed January 24, 2007.

36. Wright TC Jr, Cox JT, Massad LS, Carlson J, Twiggs LB, Wilkinson EJ; American Society for Colposcopy and Cervical Pathology. 2001 consensus guidelines for the management of women with cervical intraepithelial neoplasia. Am J Obstet Gynecol 2003;189:295-304.

37. American Society for Colposcopy and Cervical Pathology. Algorithms for the management of biopsy confirmed cervical intraepithelial neoplasia. Available at: http://www.asccp.org/pdfs/consensus/algorithms.pdf. Accessed June 20, 2007.

38. Evans MF, Adamson CS, Papillo JL, St John TL, Leiman G, Cooper K. Distribution of human papillomavirus types in ThinPrep Papanicolaou tests classified according to the Bethesda 2001 terminology and correlations with patient age and biopsy outcomes. Cancer 2006;106:1054-1064.

39. Koutsky LA, Ault KA, Wheeler CM, Brown DR, Barr E, Alvarez FB, Chiacchierini LM, Jansen KU; Proof of Principle Study Investigators. A controlled trial of a human papillomavirus type 16 vaccine. $\mathrm{N}$ Engl J Med 2002;347:1645-1651.

40. Harper DM, Franco EL, Wheeler C, Ferris DG, Jenkins D, Schuind A, Zahaf T, Innis B, Naud P, De Carvalho NS, Roteli-Martins CM, Teixeira J, Blatter MM, Korn AP, Quint W, Dubin G; GlaxoSmithKline HPV Vaccine Study Group. Efficacy of a bivalent L1 virus-like particle vaccine in prevention of infection with human papillomavirus types 16 and 18 in young women: a randomised controlled trial. Lancet 2004;364:1757-1765.

41. Villa LL, Costa RL, Petta CA, Andrade RP, Ault KA, Giuliano AR, Wheeler CM, Koutsky LA, Malm C, Lehtinen M, Skjeldestad FE, Olsson SE, Steinwall M, Brown DR, Kurman RJ, Ronnett BM, Stoler MH, Ferenczy A, Harper DM, Tamms GM, Yu J, Lupinacci L, Railkar R, Taddeo FJ, Jansen KU, Esser MT, Sings HL, Saah AJ, Barr E. Prophylactic quadrivalent human papillomavirus (types 6, 11, 16, and 18) L1 virus-like particle vaccine in young women: a randomised double-blind placebo-controlled multicentre phase II efficacy trial. Lancet Oncol 2005;6:271-278. 
42. Merck news item. Merck's investigational vaccine Gardasil ${ }^{\mathrm{TM}}$ prevented 100 percent of cervical pre-cancers and noninvasive cervical cancers associated with HPV types 16 and 18 in new clinical study. Available at: http://www.merck.com/newsroom/press_releases/research_an d_development/2005_1006.html. Accessed January 26, 2007.

43. FDA Licenses New Vaccine for Prevention of Cervical Cancer and Other Diseases in Females Caused by Human Papillomavirus. U.S. Food and Drug Administration Web site. Available at: http://www.fda.gov/bbs/topics/NEWS/2006/NEW01385.html. Accessed September 12, 2006.

44. CDC's Advisory Committee Recommends Human Papillomavirus Virus Vaccination. CDC Web site. Available at:

http://www.merck.com/newsroom/press_releases/research_an d_development/. Accessed September 12, 2006.

45. Bodaghi S, Yamanegi K, Xiao SY, Da Costa M, Palefsky JM, Zheng ZM. Colorectal papillomavirus infection in patients with colorectal cancer. Clin Cancer Res 2005;11:2862-2867.

46. Sotlar K, Koveker G, Aepinus C, Selinka HC, Kandolf R, Bultmann B. Human papillomavirus type 16-associated primary squamous cell carcinoma of the rectum. Gastroenterology 2001;120:988-994.

47. Koulos J, Symmans F, Chumas J, Nuovo G. Human papillomavirus detection in adenocarcinoma of the anus. Mod Pathol 1991;4:58-61.

48. Daling JR, Madeleine MM, Johnson LG, Schwartz SM, Shera KA, Wurscher MA, Carter JJ, Porter PL, Galloway DA, McDougall JK, Krieger JN. Penile cancer: importance of circumcision, human papillomavirus and smoking in in situ and invasive disease. Int J Cancer 2005;116:606-616.

49. Rubin MA, Kleter B, Zhou M, Ayala G, Cubilla AL, Quint WG, Pirog EC. Detection and typing of human papillomavirus DNA in penile carcinoma: evidence for multiple independent pathways of penile carcinogenesis. Am J Pathol 2001;159:1211-1218.

50. Gross G, Pfister H. Role of human papillomavirus in penile cancer, penile intraepithelial squamous cell neoplasias and in genital warts. Med Microbiol Immunol 2004;193:35-44.

51. Nagano H, Yoshikawa H, Kawana T, Yokota H, Taketani Y, Igarashi $\mathrm{H}$, Yoshikura $\mathrm{H}$, Iwamoto A. Association of multiple human papillomavirus types with vulvar neoplasias. J Obstet Gynaecol Res 1996;22:1-8.

52. Daling JR, Madeleine MM, Schwartz SM, Shera KA, Carter JJ, McKnight B, Porter PL, Galloway DA, McDougall JK, Tamimi H. A population-based study of squamous cell vaginal cancer: HPV and cofactors. Gynecol Oncol 2002;84:263-270.

53. Srodon M, Stoler MH, Baber GB, Kurman RJ. The distribution of low and high-risk HPV types in vulvar and vaginal intraepithelial neoplasia (VIN and VaIN). Am J Surg Pathol 2006;30:1513-1518.

54. Della Torre G, Donghi R, Longoni A, Pilotti S, Pasquini G, De Palo G, Pierotti MA, Rilke F, Della Porta G. HPV DNA in intraepithelial neoplasia and carcinoma of the vulva and penis. Diagn Mol Pathol 1992;1:25-30.

\section{Author Affiliations}

Folashade Ogunmodede, MD

Department of Internal Medicine

Marshfield Clinic

1000 N. Oak Avenue

Marshfield, Wisconsin 54449
Steven H. Yale, MD

Department of Internal Medicine

Marshfield Clinic, and

Clinical Research Center

Marshfield Clinic Research Foundation

1000 N. Oak Avenue

Marshfield, Wisconsin 54449

Bruce Krawisz, MD

Department of Pathology

Marshfield Clinic

1000 N. Oak Avenue

Marshfield, Wisconsin 54449

Gregory C. Tyler, MD

Department of Obstetrics and Gynecology

Marshfield Clinic

1000 N. Oak Avenue

Marshfield, Wisconsin 54449

Anthony C. Evans, MD, PhD

Division of Gynecologic Oncology

University of Wisconsin

600 Highland Avenue, H4/636

Madison, Wisconsin 53792 